\title{
Studi Niat Pelaporan Pelanggaran: Tinjauan Literatur Dalam Prilaku Organisasi Mengenai Moral dan Rasa Takut Karyawan Akan Pembalasan
}

\author{
Muhammad Fikry Aransyah ${ }^{1, *}$, Adietya Arie Hetami ${ }^{2}, \&$ Putery Satriani Ramba ${ }^{3}$ \\ ${ }^{1,2,3}$ Fakultas Ilmu Sosial dan Ilmu Politik, Universitas Mulawarman, Samarinda, Indonesia \\ "Email: fikry.aransyah@fisip.unmul.ac.id
}

\begin{abstract}
This study summarize literature that review whistleblowing. This study seeks detailed information and empirical data regarding the factors that influence the whistleblowing intention studies in literature review research. Applying the Moral Intensity Model introduced by Jones (1991), the artikel looks into how magnitude of consequences, social consensus, and proximity affect whistleblowing intention. Besides, fear of retaliation is an additional variable to extend the study based on Moral Intensity Model. The first variabel is the magnitude of consequences. Studies related to this predictor examine the harms or benefits done to victims or beneficiaries of the moral act in question. The studies related to the second variabel, social consensus, examine The degree of social agreement that a proposed act is evil or good. The third variabel is the proximity. Studies in this area focus on the feeling of nearness (social, cultural, psychological, or physical) that the moral agent has for victims of the evil act in question. Studies related to the final variabel, fear of retaliation, examine as unwanted action against a whistleblower resulting from internal or external whistleblowing. For each variabel, authors first summarize and analyze previous research findings and then put forward suggestions for future whistleblowing research.
\end{abstract}

\begin{abstract}
Abstraksi: Studi ini mempelajari dan meringkas literatur yang mengulas pelaporan pelanggaran. Penelitian ini mencari informasi rinci dan data empiris mengenai faktor-faktor yang mempengaruhi studi niat pelaporan pelanggaran dalam riset kajian literatur. Dengan menerapkan Model Intensitas Moral yang diperkenalkan oleh Jones (1991), artikel ini melihat bagaimana besarnya konsekuensi, konsensus sosial, dan kedekatan mempengaruhi niat pelaporan pelanggaran. Selain itu, ketakutan akan pembalasan adalah variabel tambahan untuk memperpanjang studi berdasarkan Model Intensitas Moral. Variabel pertama adalah besarnya konsekuensi. Studi yang berkaitan dengan variabel ini memeriksa bahaya atau manfaat yang dilakukan pada korban atau penerima manfaat dari tindakan moral yang dimaksud. Studi yang terkait dengan variabel kedua, konsensus sosial, memeriksa tingkat persetujuan sosial bahwa tindakan yang diusulkan itu jahat atau baik. Variabel ketiga adalah kedekatan. Studi-studi dalam bidang ini berfokus pada perasaan kedekatan (sosial, budaya, psikologis, atau fisik) yang dimiliki agen moral bagi para korban kejahatan yang dipertanyakan. Studi yang terkait dengan variabel akhir, rasa takut akan pembalasan, rasa takut atas tindakan yang tidak diinginkan oleh pelapor yang disebabkan oleh kondisi internal atau eksternal. Untuk setiap variabel, penulis meringkas dan menganalisis temuan penelitian sebelumnya dan kemudian mengajukan saran untuk penelitian pelaporan pelanggaran di masa depan.
\end{abstract}

Keywords: Literature review; Whistleblowing; Whistleblowing Intention; Moral Intensity; Fear Of Retaliation

\section{Pendahuluan}

Pelaporan Pelanggaran (whistle blowing) kini telah berubah menjadi mekanisme akuntabilitas dan manajemen risiko, pada serangkaian skandal perusahaan (Mustapha \& Siaw, 2012). Untuk mengurangi risiko penipuan dan melindungi kepentingan pemegang saham, organisasi harus berinvestasi dalam mekanisme pelaporan pelanggaran resmi dan mendorong karyawan untuk melaporkan kesalahan.
Karyawan yang melaporkan kekhawatiran tentang kesalahan perusahaan secara dini dapat membantu mengurangi tingkat konsekuensi kesalahan (Chartered Institute of Internal Auditor [IIA], 2014). Ketika karyawan memilih untuk tetap diam dan membiarkan kesalahan terus berlanjut, konsekuensi yang mungkin dapat merugikan profitabilitas organisasi, moral karyawan dan minat pemegang saham dalam jangka panjang dan bahkan menyebabkan hilangnya 
nyawa di dallam perusahaan (Mela, Zarefar, \& Andreas, 2016).

Penelitian yang sebelumnya telah dilakukan untuk memeriksa faktor-faktor yang memotivasi pelaporan pelanggaran dan faktor-faktor yang mempengaruhi kecenderungan melaporkan pelaporan pelanggaran. Studi empiris sebelumnya pada dasarnya berfokus pada peran variabel demografis, personal, situasional, dan organisasi dalam niat pelaporan pelanggaran (Ahmad, 2011). Namun, penelitian yang belum mencakup semua variabel yang relevan dan dapat mempengaruhi niat pelaporan pelanggaran (Miceli, Near, Rehg, \& Van Scotter, 2012). Selain itu, sebagian besar penelitian yang sebelumnya muncul dalam konteks Barat, bukan dalam konteks Timur (Salleh \& Yunus, 2015). Meskipun minat terhadap isu pelaporan pelanggaran ada dalam konteks Asia, tetapi studi bersifat terbatas pada negara-negara seperti Tiongkok, Hong Kong, dan Taiwan serta ada juga studi empiris tentang pelaporan pelanggaran di Indonesia (Ahmad, Smith, \& Ismail, 2012). Selain itu, perlu untuk menekankan pentingnya perbedaan nasional dan budaya dalam memeriksa isu-isu pelaporan pelanggaran (Ahmad, 2011). Studi pelaporan pelanggaran yang dilakukan di berbagai negara tidak dapat diterapkan sepenuhnya untuk mengatasi masalah di Indonesia. Sehingga penting dilaksanakannya riset literatur untuk memperluas wawasan mengenai variabel pelaporan pelanggaran yang masih terbatas.

\section{Kajian Teori}

\section{Konsep Pelaporan Pelanggaran dalam Prilaku Organisasi}

Pelaporan pelanggaran mengacu pada tindakan anggota organisasi yang sudah terjadi atau mantan anggota organisasi yang menemukan perilaku ilegal, tidak etis, atau tidak teratur dalam suatu organisasi dan pelaporan pelanggaran kepada individu atau organisasi yang dapat mempengaruhi perilaku tersebut (Near dan Miceli, 1985). Perilaku pelaporan pelanggaran mencakup dua metode: satu adalah pelaporan pelanggaran internal, yang menunjuk pada kepemimpinan dan manajemen dalam organisasi untuk melaporkan masalah; yang lainnya adalah pelaporan pelanggaran eksternal dengan menunjuk pada masalah pelaporan pelanggaran oleh lembaga pemerintah, media atau organisasi profesional. Individu yang mengamati terjadinya pelanggaran, tidak akan berprilaku sama dengan ketika mereka mendeteksi keadaan darurat (seperti kebakaran atau peristiwa berdarah), dan mereka memiliki waktu yang cukup untuk membuat keputusan dalam situasi sebelumnya. Studi telah mengembangkan model proses pengambilan keputusan dari Model Perilaku Organisasi Prososial dan Model Intensitas Moral.

\section{Model Prosocial Organizational Behavior (POB)}

Dozier (1985) menggunakan model POB untuk menggambarkan proses pengambilan keputusan pelaporan pelanggaran: 1) persepsi pelanggaran, yaitu, apakah telah dilaporkan atau diperbaiki; 2) analisis sinyal yang ditransmisikan oleh pelanggaran dan sejauh mana kerusakan yang ditimbulkan, seperti adanya tingkat kerusakan psikologis yang disebabkan oleh karyawan? 3) untuk menentukan apakah mereka memiliki tanggung jawab dan kemampuan untuk pelaporan pelanggaran dan mencegah pelanggaran sementara menilai manfaat dan biaya yang diharapkan dari tindakan pelaporan pelanggaran; 4) menghasilkan niat dan perilaku (Dozier dan Miceli, 1985). Model POB mengikuti proses pengambilan keputusan yang rasional secara ekonomi yang mempertimbangkan analisis "biayamanfaat" dari tindakan pelaporan pelanggaran. Pengamat hanya akan mengambil tindakan ketika manfaat yang diharapkan lebih tinggi dari biaya. Oleh karena itu, model POB adalah model pengambilan keputusan yang berorientasi pada hasil.

Studi empiris berdasarkan model POB adalah yang paling umum digunakan oleh peneliti. Para peneliti memverifikasi pengaruh variabel independen yang berbeda terhadap keputusan pelaporan pelanggaran. Mereka menjelaskan bahwa mekanisme tindakan internal adalah faktor individu atau 
kontekstual yang bekerja pada kognisi psikologis pengamat, yang mempengaruhi keputusan pelapor pelanggaran dengan mempengaruhi analisis biaya-manfaat. Misalnya, Keil et al. (2010) menemukan bahwa iklim organisasi yang positif dan kepercayaan atasan mendorong niat pelaporan pelanggaran melalui peran perantara analisis biaya-manfaat (Keil et al. 2010); Gaudine et al. (2001) menemukan bahwa karyawan dengan emosi positif memiliki bias positif terhadap penilaian hasil pelaporan pelanggaran. Oleh karena itu, emosi positif mempromosikan niat pelaporan pelanggaran. Emosi positif berasal dari seberapa kuat intensitas moral yang dimiliki. Moral menjadi variabel selanjutnya yang akan mempengaruhi pelapor untuk memutuskan niatnya. Sehingga diperlukan kajian teori selanjutnya yakni Model Intensitas Moral untuk mengenali niat pelapor pelanggaran.

\section{Model Intensitas Moral}

Model Intensitas Moral diperkenalkan oleh Thomas M. Jones pada tahun 1991. Intensitas moral digambarkan sebagai berikut "sebuah model yang menangkap sejauh mana imperatif moral terkait masalah dalam suatu situasi" (Jones, 1991). Munculnya intensitas moral adalah karena dampak dari masalah moral yang diabaikan dalam teori-teori pengambilan keputusan etis (Smith, Kistruck, \& Cannatelli, 2016). Jones membuat konsep modelnya berdasarkan Rest's FourComponent Model yang terdiri dari mengenali masalah moral, penilaian moral, intensi moral dan perilaku moral (Lincoln \&
Holmes, 2011). Oleh karena itu, ketika intensitas moral yang dirasakan tinggi, masalah moral diakui, penilaian moral dipicu, intensi moral ditetapkan mengakibatkan individu akan terlibat dalam perilaku moral. Model Intensitas Moral telah diadopsi secara luas di berbagai bidang penelitian. Tabel 1 menunjukkan penelitian terdahulu yang dilakukan tentang pengaruh intensitas moral terhadap pengambilan keputusan etis.

Jones (1991) melaporkan bahwa ada hubungan antara semua dimensi dan intensitas moral. Misalkan, peningkatan dalam salah satu dimensi dalam intensitas moral akan meningkatkan tingkat dari intensitas moral, dengan asumsi dimensi lain tetap konstan. Jones (1991) lebih lanjut menekankan bahwa dimensi-dimensi yang mewakili karakteristik masalah moral ini memiliki efek berulang satu sama lain.

Oleh karena itu, keputusan etis akan dianggap memiliki tingkat intensitas moral yang tinggi ketika tindakan tersebut dianggap tidak etis oleh kebanyakan orang (Shawver, 2011). Besaran Konsekuensi, Konsensus Sosial dan Kedekatan menjadi alasan dan dianggap sebagai variabel signifikan dari intensi moral (Wang et al., 2015; Lincoln \& Holmes, 2011; Arnold Sr et al., 2013). Selain itu, ketiga dimensi ini juga membentuk dimensi tunggal yang memprediksi intensi moral (Barnett dalam Leitsch, 2006).

Survei menunjukkan bahwa sebagian besar individu menolak untuk memberitahu

Tabel 1. Penerapan Model Intensitas Moral dalam studi sebelumnya

\begin{tabular}{lll}
\hline \multicolumn{1}{c}{ Penulis } & \multicolumn{1}{c}{ Area Penelitian } & \multicolumn{1}{c}{ Deskripsi } \\
Wang, Keil, dan & $\begin{array}{l}\text { Teknologi Informasi } \\
\text { Wang (2015) }\end{array}$ & $\begin{array}{l}\text { Untuk mempelajari pengaruh intensitas moral pada } \\
\text { pelaporan berita buruk dari karyawan. }\end{array}$ \\
\hline Shawver (2011) & Manajemen laba & $\begin{array}{l}\text { Untuk menguji bagaimana intensitas moral berhubungan } \\
\text { dengan pelaporan pelanggaran pada karyawan manajemen } \\
\text { laba. }\end{array}$ \\
\hline $\begin{array}{ll}\text { Bhal dan Dadhich } \\
\text { (2011) }\end{array}$ & $\begin{array}{l}\text { Manajemen dan } \\
\text { Administrasi }\end{array}$ & $\begin{array}{l}\text { Untuk menjelaskan bagaimana intensitas moral memoderasi } \\
\text { pengaruh kepemimpinan etis dan pertukaran pemimpin- } \\
\text { anggota pada pelaporan pelanggaran. }\end{array}$ \\
\hline $\begin{array}{l}\text { Arnold et. al } \\
\text { (2013) }\end{array}$ & Akuntansi dan audit & $\begin{array}{l}\text { Untuk menguji pengaruh intensitas moral pada pengambilan } \\
\text { keputusan etis dan penilaian auditor internal, auditor }\end{array}$ \\
& & $\begin{array}{l}\text { eksternal dari perusahaan internasional yang lebih besar dan } \\
\text { dari perusahaan regional. }\end{array}$ \\
\hline
\end{tabular}


siapa pelakunya karena mereka takut akan pembalasan (Wainburg \& Perreault, 2016). Dengan demikian, pembalasan terhadap si pelapor telah menjadi variabel pada penelitian sebelumnya (Kennett et al., 2011). Selain itu, rasa takut yang merupakan faktor situasional (sebagaimana dinyatakan dalam Cassematis \& Wortley, 2013) akan membuat penelitian ini lebih komplemen karena intensitas moral juga merupakan faktor situasional (seperti yang disediakan dalam Wang et al., 2015).

Pelaporan pelanggaran adalah keputusan etis yang tepat yang akan mempengaruhi tingkat intensitas moral (Clements \& Shawver, 2011). Studi ini tidak memasukkan perilaku moral dalam investigasi karena kesulitan untuk menyelidiki kasus-kasus pelaporan pelanggaran aktual dalam organisasi dan untuk mendekati si pengadu yang sebenarnya untuk ditanyai (Sampaio \& Sobral, 2013).

\section{Pembahasan}

\section{Niat Pelaporan Pelanggaran}

Near dan Miceli (sebagaimana dikutip oleh Kennett et al., 2011) mendefinisikan pelaporan pelanggaran sebagai "pengungkapan oleh anggota organisasi (sebelumnya atau saat ini) mengenai praktik ilegal, tidak bermoral, atau tidak sah kepada orang atau organisasi yang mungkin dapat melakukan tindakan". Namun, niat pelaporan pelanggaran mengacu pada "probabilitas bahwa seseorang akan terlibat dalam perilaku pelaporan pelanggaran yang sebenarnya" (Chiu, 2002).

Secara umum, ada dua jenis pelapor. Pelapor internal adalah pelapor yang melaporkan kesalahan kepada pihak internal dalam organisasi seperti manajemen senior, sedangkan pelapor eksternal mengajukan keluhan kepada pihak ketiga seperti pemerintah atau regulator hukum. Penelitian ini berkenaan dengan efek keseluruhan dari intensitas moral pada niat pelaporan pelanggaran dan karenanya, tidak membedakan antara pelaporan pelanggaran internal atau eksternal.
Salah satu penelitian sebelumnya tentang pelaporan pelanggaran dilakukan oleh Erkman et al. (2012) menganalisis apakah akuntansi profesional Turki akan mengadu ketika melihat kesalahan serius di tempat kerja. Namun, temuan empiris mereka berdasarkan pada tiga situasi pelaporan pelanggaran memiliki nilai rata-rata dalam menunjukkan kecenderungan moderat peserta untuk berbicara. Penelitian oleh Kennett et al. (2014) meneliti tentang niat petugas administrasi dalam melaporkan kasus penipuan keuangan besar-besaran secara eksternal, dengan mempertimbangkan konsekuensi pribadi dan potensial sosial dari pelaporan pelanggaran. Temuan menunjukkan bahwa sekitar $75 \%$ dari peserta cenderung berbicara, tetapi tidak ada yang yakin mereka akan berbicara. Chiu (2002) meneliti mengenai pertimbangan etis, locus of control, dan niat pelaporan pelanggaran pada kasus siswa Master Administrasi Bisnis Tiongkok dan menunjukan bahwa dua penghalang utama terhadap niat pelaporan pelanggaran di Tiongkok adalah moralitas dan etika.

Studi lain oleh Mustapha dan Siaw (2012) berusaha untuk menentukan persepsi pelaporan pelanggaran akuntan masa depan dan bagaimana keseriusan kesalahan, gender, dan kinerja akademik mempengaruhi niat pelaporan pelanggaran di antara mahasiswa akuntansi dan bisnis tahun terakhir di Universitas Negeri Malaysia. Hasil penelitian menunjukkan bahwa sebagian besar memahami pentingnya pelaporan pelanggaran dan telah mengambil metode yang biasa untuk kemauan pelaporan pelanggaran. Mereka cenderung menerapkan strategi "menunggu dan melihat", tetapi hanya ketika ada kebutuhan.

Studi oleh Fatoki (2013) meneliti pemahaman mahasiswa akuntansi dan bisnis tahun lalu tentang pelaporan pelanggaran dalam hal intensitas pembalasan, materialitas, dan gender. Hasilnya mengungkapkan bahwa sebagian besar responden menganggap pengadu sebagai pahlawan dan menyetujui pentingnya mengadu dalam meningkatkan minat publik dan mengurangi korupsi, penipuan, dan salah kelola. 
Tabel 2. Ringkasan Landasan Empiris Niat Pelaporan Pelanggaran

\begin{tabular}{|c|c|c|c|}
\hline Studi & Negara & Metode & Temuan Utama \\
\hline $\begin{array}{l}\text { Erkmen et } \\
\text { al. (2014) }\end{array}$ & Turki & $\begin{array}{l}\text { Tiga skenario kuesioner dari } 116 \\
\text { profesional akuntansi di Turki. }\end{array}$ & $\begin{array}{l}\text { Responden memiliki } \\
\text { kecenderungan ringan untuk } \\
\text { mengadu. }\end{array}$ \\
\hline $\begin{array}{l}\text { Kennett et } \\
\text { al. (2011) }\end{array}$ & $\begin{array}{l}\text { Amerika } \\
\text { Serikat }\end{array}$ & $\begin{array}{l}\text { Survei kuesioner kasus dari } 81 \text { jurusan } \\
\text { akuntansi dalam dua kursus akuntansi } \\
\text { tingkat senior di universitas Mid-western } \\
\text { regional. }\end{array}$ & $\begin{array}{l}75 \% \text { dari peserta cenderung } \\
\text { mengadu, tetapi tidak ada yang } \\
\text { yakin mereka akan mengadu. }\end{array}$ \\
\hline $\begin{array}{l}\text { Mustapha } \\
\text { dan Siaw } \\
(2012)\end{array}$ & Malaysia & $\begin{array}{l}\text { Kuisioner terhadap } 150 \text { mahasiswa } \\
\text { akuntansi tahun terakhir di universitas } \\
\text { negeri sebagai responden mereka. } \\
\text { Namun, hanya } 105 \text { kuesioner yang } \\
\text { dikembalikan dan dapat digunakan. }\end{array}$ & $\begin{array}{l}\text { Mayoritas tampaknya memahami } \\
\text { pentingnya pelaporan pelanggaran } \\
\text { dan mengambil pendekatan yang } \\
\text { relatif moderat terhadap keinginan } \\
\text { untuk mengadu. }\end{array}$ \\
\hline $\begin{array}{l}\text { Fatoki } \\
(2013)\end{array}$ & $\begin{array}{l}\text { Selatan } \\
\text { Afrika }\end{array}$ & $\begin{array}{l}\text { Kuesioner dikumpulkan dari total } 219 \\
\text { dari } 250 \text { mahasiswa akuntansi tahun } \\
\text { terakhir dari dua universitas berbeda di } \\
\text { provinsi Gauteng di Afrika Selatan. }\end{array}$ & $\begin{array}{l}\text { Sebagian besar responden } \\
\text { menganggap pengadu sebagai } \\
\text { pahlawan dan menyetujui } \\
\text { pentingnya pelaporan pelanggaran. }\end{array}$ \\
\hline $\begin{array}{l}\text { Alleyne et } \\
\text { al. (2013) }\end{array}$ & Barbados & $\begin{array}{l}\text { Kuesioner yang dikelola sendiri dari } 500 \\
\text { auditor external dari organisasi di } \\
\text { Barbados. Hanya } 236 \text { yang dapat } \\
\text { digunakan. }\end{array}$ & $\begin{array}{l}\text { Auditor tidak mungkin mengadu } \\
\text { atau membuat pelaporan } \\
\text { pelanggaran. }\end{array}$ \\
\hline
\end{tabular}

Sumber: Data diolah (2019)

Penelitian lain meneliti bagaimana komitmen organisasi dan nilai-nilai etika perusahaan mempengaruhi persepsi karyawan akuntan tentang pelaporan pelanggaran di Barbados. Namun, analisis data menunjukkan bahwa karyawan tidak mungkin untuk membuat pelaporan pelanggaran meskipun mengungkapkan pelaporan pelanggaran bukan dianggap sebagai tindakan yang salah (Alleyne, Weekes-Marshall, \& Arthur, 2013).

\section{Besaran Konsekuensi}

Shawver and Clements (2015) mendefinisikan Besaran Konsekuensi sebagai "bahaya atau manfaat bagi individu yang timbul dari suatu tindakan". Valentine dan Hollingworth (2012) juga menganggap Besaran Konsekuensi sebagai dampak yang serius dari tindakan yang tidak etis. Sampaio dan Sobral (2013) menyatakan bahwa Besaran Konsekuensi berhubungan dengan sejauh mana seorang individu berhubungan dengan konsekuensi dari masalah moral, (yaitu, kesalahan yang serius). Sebagai ilustrasi, masalah yang menyebabkan hilangnya nyawa memiliki besaran konsekuensi yang lebih besar daripada masalah yang hanya menyebabkan korban menderita cedera ringan (Smith et al., 2016). Individu menganggap pelaporan pelanggaran sebagai hal yang memiliki kasus yang lebih serius dan meyakinkan mereka bahwa pelaporan pelanggaran adalah tindakan yang tepat (Sampaio \& Sobral, 2013).

Sebuah studi oleh Wang et al. (2015) mengusulkan model penelitian yang menguji niat insinyur perangkat lunak untuk melaporkan bug sistem TI berdasarkan intensitas moral dan penilaian moralitas. Hasilnya menunjukkan bahwa besaran konsekuensi memiliki efek langsung pada kesediaan karyawan untuk melaporkan berita buruk. Artikel lain meneliti tentang pengaruh dukungan yang dirasakan, nilai-nilai

organisasi atau budaya, dan kesalahan pada niat berbicara secara internal antara 250 personil manajemen dan administrasi. Hasil ini memberikan dukungan bahwa dampak kesalahan secara positif terkait dengan niat untuk menggadu (Pillay, Dorasamy, \& Vranic, 2012).

Studi oleh Ballantine (2002) meneliti pengaruh intensitas moral terhadap niat etis diantara mahasiswa sarjana pemasaran dari Malaysia dan Selandia Baru. Temuan mendukung bahwa besaran konsekuensi memiliki hubungan penting dengan niat etis subyek. Penelitian oleh Arnold et al. (2013) menyelidiki pengaruh konteks situasional 
Tabel 3. Ringkasan Landasan Empiris Besaran Konsekuensi

\begin{tabular}{|c|c|c|c|}
\hline Studi & Negara & Metode & Temuan Utama \\
\hline $\begin{array}{l}\text { Wang et } \\
\text { al. }(2015)\end{array}$ & China & $\begin{array}{l}\text { Survei Online terhadap } 173 \\
\text { insinyur perangkat lunak } \\
\text { Tiongkok. }\end{array}$ & $\begin{array}{l}\text { Besarnya konsekuensi memiliki efek langsung } \\
\text { pada kesediaan karyawan untuk melaporkan } \\
\text { berita buruk. }\end{array}$ \\
\hline $\begin{array}{l}\text { Pillay et } \\
\text { al. }(2012)\end{array}$ & $\begin{array}{l}\text { Afrika } \\
\text { Selatan }\end{array}$ & $\begin{array}{l}\text { Total } 506 \text { kuesioner dibagikan } \\
\text { kepada } 250 \text { personel manajemen } \\
\text { atau administrasi tingkat senior, } \\
\text { menengah dan bawah dari lima } \\
\text { departemen Pemerintah Nasional. }\end{array}$ & $\begin{array}{l}\text { Dampak kegiatan tidak bermoral atau ilegal } \\
\text { lebih besar; niat untuk pelaporan pelanggaran } \\
\text { lebih besar. }\end{array}$ \\
\hline $\begin{array}{l}\text { Ballantine } \\
(2002)\end{array}$ & $\begin{array}{l}\text { New } \\
\text { Zealand }\end{array}$ & $\begin{array}{l}\text { Kuesioner dengan tiga skenario } \\
\text { etika untuk } 45 \text { mahasiswa } \\
\text { pemasaran sarjana Malaysia dan } \\
82 \text { Selandia Baru. }\end{array}$ & $\begin{array}{l}\text { Besarnya konsekuensi adalah variabel niat etis } \\
\text { yang paling konsisten. }\end{array}$ \\
\hline $\begin{array}{l}\text { Arnold et } \\
\text { al. (2013) }\end{array}$ & $\begin{array}{l}\text { United } \\
\text { States }\end{array}$ & $\begin{array}{l}\text { Kuesioner kepada } 71 \text { akuntan } \\
\text { non-Big-4, } 32 \text { auditor tingkat } \\
\text { senior dari perusahaan Big- } 4 \text { dan } \\
43 \text { auditor internal. }\end{array}$ & Besarnya konsekuensi memengaruhi niat etis. \\
\hline
\end{tabular}

Sumber : Data diolah (2019)

pada pengambilan keputusan etis dan evaluasi penilaian antara auditor internal dan auditor eksternal dari perusahaan kecil dan perusahaan internasional. Analisis hasil mendukung hipotesis bahwa Besaran Konsekuensi memengaruhi evaluasi etis dan niat untuk bertindak secara etis.

\section{Konsensus Sosial}

Definisi Konsensus Sosial (Chen dan Lai, 2014) adalah "sejauh mana kesepakatan sosial tentang tindakan tersebut jahat atau baik". Studi tentang Musbah, Cowton dan Tyfa (2016) menyebut Konsensus Sosial sebagai "tingkat penerimaan sosial tentang tindakan yang diberikan itu baik atau jahat". Konsensus Sosial juga didefinisikan sebagai perjanjian tentang tindakan negatif (Valentine \& Hollingworth, 2012). Konsensus Sosial juga dianggap sebagai norma sosial dimana individu umumnya didasarkan pada harapan orang lain untuk merasionalisasi tindakan (Bateman, Valentine, \& Rittenburg, 2013). Ketika orang-orang yang dekat dengannya menyetujui atau menyetujui perilaku tersebut, seorang individu akan merasa kurang bimbang dan lebih mungkin terlibat dalam perilaku etis (Trongmateerut \& Sweeney, 2013).
Sebuah studi oleh Sweeney dan Costello (2009) mengeksplorasi bagaimana intensitas moral yang dirasakan mempengaruhi identifikasi dilema etis, penilaian etis, niat etis untuk mahasiswa sarjana akuntansi dan bisnis tahun ketiga. Studi mereka memberikan dukungan empiris bahwa Konsensus Sosial memiliki hubungan terkuat dalam pengambilan keputusan etis, dibandingkan dengan komponen lainnya. Schmidtke (2007) melakukan penelitian tentang reaksi pengamat terhadap pencurian rekan kerja sehubungan dengan Konsensus Sosial dan kesamaan yang dirasakan pada 223 karyawan non-pengawas dari restoran. Hasil penelitian menunjukkan bahwa Konsensus Sosial memiliki hubungan yang tidak signifikan dengan pelaporan pencurian.

Shawver and Clements (2011) mempelajari pengaruh persepsi Konsensus Sosial pada pelaporan manajemen laba secara internal dengan berlatih akuntan. Studi mereka menemukan bahwa Konsensus Sosial merupakan faktor penting dalam keputusan untuk mengadu. Chen dan Lai (2014) meneliti dampak intensitas moral (potensi bahaya dan tekanan sosial) pada niat pelaporan pelanggaran dan perilaku, yang ditengahi oleh komitmen organisasi. Temuan 
menunjukkan bahwa tidak ada hubungan yang signifikan antara tekanan sosial dan niat pelaporan pelanggaran. Penelitian lain mempelajari hubungan tiga dimensi moral dengan pengambilan keputusan etis dari 229 akuntan Libya. Hasil penelitian menunjukkan bahwa Konsensus Sosial memiliki signifikansi terbatas pada niat etis (Musbah, Cowton \& Tyfa, 2016).
Studi tentang Singer et al. (seperti dikutip dalam Taylor \& Curtis, 2013) mengemukakan bahwa ketika agen moral dekat dengan korban dari tindakan yang dipertanyakan, empati yang dirasakan akan lebih besar dan mempengaruhi niat pelaporan pelanggaran. Sebagai contoh, efek Kedekatan lebih besar ketika PHK terjadi di perusahaan kita sendiri daripada di perusahaan lain

Tabel. 4. Ringkasan Landasan Empiris Besaran Konsekuensi

\begin{tabular}{|c|c|c|c|}
\hline Studi & Negara & Metode & Temuan Utama \\
\hline $\begin{array}{l}\text { Sweeney } \\
\text { dan } \\
\text { Costello } \\
(2009)\end{array}$ & Irlandia & $\begin{array}{l}\text { Kuisioner dikumpulkan dari } 191 \\
\text { siswa bisnis tahun ketiga di mana } 104 \\
\text { adalah mahasiswa akuntansi dan } 87 \\
\text { adalah mahasiswa non-akuntansi. }\end{array}$ & $\begin{array}{l}\text { Konsensus sosial memiliki hubungan } \\
\text { terkuat dengan pengambilan keputusan } \\
\text { etis. }\end{array}$ \\
\hline $\begin{array}{l}\text { Shawver } \\
\text { and } \\
\text { Clements } \\
(2011)\end{array}$ & $\begin{array}{l}\text { Amerika } \\
\text { Serikat }\end{array}$ & $\begin{array}{l}\text { Kuesioner berbasis skenariodari } 957 \\
\text { akuntan publik bersertifikat, } 192 \\
\text { setuju untuk berpartisipasi dan } 171 \\
\text { tanggapan yang dapat digunakan } \\
\text { dikumpulkan. }\end{array}$ & $\begin{array}{l}\text { Konsensus sosial sebagai faktor yang harus } \\
\text { dipertimbangkan oleh akuntan ketika } \\
\text { memutuskan untuk pelaporan pelanggaran. }\end{array}$ \\
\hline $\begin{array}{l}\text { Schmidtke } \\
(2007)\end{array}$ & $\begin{array}{l}\text { Amerika } \\
\text { Serikat }\end{array}$ & $\begin{array}{lll}\text { Data Survei } & \text { dikumpulkan dari } 223 \\
\text { karyawan } & \text { non-pengawas } & \text { dari } \\
\text { restoran. } & & \end{array}$ & $\begin{array}{l}\text { Konsensus sosial memiliki hubungan yang } \\
\text { tidak signifikan dengan melaporkan } \\
\text { pencurian. }\end{array}$ \\
\hline $\begin{array}{l}\text { Chen dan } \\
\text { Lai }(2014)\end{array}$ & Taiwan & $\begin{array}{l}\text { Kuesioner online berbasis scenario } \\
\text { atas } 533 \text { karyawan dari sektor } \\
\text { manufaktur, layanan, dan publik. }\end{array}$ & $\begin{array}{l}\text { Tidak ada hubungan yang signifikan antara } \\
\text { tekanan sosial dan niat pelaporan } \\
\text { pelanggaran. }\end{array}$ \\
\hline $\begin{array}{l}\text { Musbah et } \\
\text { al. }(2016)\end{array}$ & Libya & $\begin{array}{l}\text { Kuesioner termasuk empat skenario } \\
\text { etika berbeda dari } 229 \text { manajemen } \\
\text { keuangan. }\end{array}$ & $\begin{array}{l}\text { Konsensus sosial memiliki signifikansi } \\
\text { terbatas pada niat etis. }\end{array}$ \\
\hline
\end{tabular}

Sumber : Data diolah (2019)

\section{Kedekatan}

Mencl dan May (2009) menggambarkan Kedekatan sebagai "tingkat kedekatan antara korban atau penerima tindakan moral dan agen moral". Definisi Kedekatan oleh Shawver (2011) mengacu pada seberapa dekat secara sosial, budaya, dan fisik dari korban tindakan moral terhadap pembuat keputusan. Kedekatan diukur sebagai "kedekatan dengan mereka yang dirugikan oleh dampak masalah moral" (Valentine \& Hollingworth, 2012). Ketika para korban memiliki hubungan dekat dengan seorang individu, korban akan lebih cenderung khawatir dan penilaian moral mereka akan meningkatkan kemauan untuk melaporkan berita buruk (Lincoln \& Holmes, 2011).
(Shawver, 2011).

Studi oleh Carlson, Kacmar, dan Wadsworth (2009) meneliti dampak dari tiga dimensi intensitas moral (efek konsentrasi, efek kedekatan, dan efek probabilitas) pada pengambilan keputusan etis mahasiswa tingkat senior. Hasil yang mendukung hipotesis adalah bahwa kedekatan individu dan korban memiliki hubungan positif dengan persepsi etis dari tindakan yang terlibat. Studi lain oleh Lincoln dan Holmes (2011) menyelidiki hubungan lima komponen intensitas moral dengan kesadaran moral, penilaian moral, dan niat moral diantara siswa yang menghadiri layanan akademik. Temuan empiris menunjukkan 
bahwa Kedekatan memiliki hubungan yang erat dengan niat moral.

Studi tentang Wang et al. (2015) mengusulkan sebuah model untuk mempelajari pengaruh intensitas moral pada niat karyawan untuk melaporkan bug pada sistem. Berdasarkan data survei yang dikumpulkan dari 173 insinyur perangkat lunak, hasilnya mengungkapkan bahwa tanggapan langsung terhadap pelapor (Erkmen et al., 2014). Contoh konsekuensi potensial dari melaporkan kesalahan mungkin dipecat atau pensiun dini, sulit untuk mendapatkan pekerjaan, dihina atau dilecehkan dan menderita tuduhan palsu tentang karakter dan perilaku pelapor (Kennett et al., 2011).

Kennett et al. (2011) mempelajari niat

Tabel 5. Ringkasan Landasan Empiris Kedekatan

\begin{tabular}{|c|c|c|c|}
\hline Studi & Negara & Metode & Temuan Utama \\
\hline Carlson et al. (2009) & $\begin{array}{l}\text { Amerika } \\
\text { Serikat }\end{array}$ & $\begin{array}{l}\text { Kuisioner dikumpulkan dari } \\
337 \text { mahasiswa tingkat atas } \\
\text { dari sebuah universitas besar } \\
\text { di selatan. }\end{array}$ & $\begin{array}{l}\text { Kedekatan individu dan korban } \\
\text { memiliki hubungan positif dengan } \\
\text { persepsi etis dari tindakan yang } \\
\text { terlibat. }\end{array}$ \\
\hline Wang et al. (2015) & China & $\begin{array}{l}\text { Survei Online terhadap } 173 \\
\text { insinyur perangkat lunak } \\
\text { Tiongkok. }\end{array}$ & $\begin{array}{l}\text { Kedekatan memiliki hubungan yang } \\
\text { tidak signifikan dengan niat } \\
\text { pelaporan berita buruk. }\end{array}$ \\
\hline $\begin{array}{l}\text { Lincoln dan Holmes } \\
\text { (2011) }\end{array}$ & Kanada & $\begin{array}{l}\text { Survei komputer Anonim dari } \\
812 \text { siswa menghadiri akademi } \\
\text { layanan. }\end{array}$ & $\begin{array}{l}\text { Kedekatan memiliki hubungan } \\
\text { moderat dengan niat moral. }\end{array}$ \\
\hline $\begin{array}{l}\text { Mencl dan May } \\
(2009)\end{array}$ & $\begin{array}{l}\text { Amerika } \\
\text { Serikat }\end{array}$ & $\begin{array}{l}\text { Kuesioner berbasis } 93 \text { orang } \\
\text { profesional sumber daya } \\
\text { manusia dari Midwestern. }\end{array}$ & $\begin{array}{l}\text { Kedekatan tidak memiliki hubungan } \\
\text { dengan pengambilan keputusan etis. }\end{array}$ \\
\hline
\end{tabular}

Sumber : Data diolah (2019)

Kedekatan kepada para korban secara tidak langsung mempengaruhi niat pelaporan berita buruk melalui penilaian moral. Penelitian oleh Mencl dan May (2009) mengeksplorasi pengaruh Besaran Konsekuensi dan berbagai jenis Kedekatan (sosial, psikologis, dan fisik) pada proses pengambilan keputusan etis para sumber daya manusia profesional. Temuan menunjukkan bahwa Kedekatan tidak mempengaruhi pengambilan keputusan etis.

\section{Rasa Takut Akan Pembalasan}

Beberapa orang tidak memilih untuk melaporkan pelanggaran karena mereka takut akan kemungkinan pembalasan terhadap mereka (Wainberg \& Perreault, 2016). Pembalasan didefinisikan sebagai tindakan yang tidak diinginkan terhadap pelapor yang disebabkan oleh pelapor internal atau eksternal (Rehg, Miceli, Near, \& Van Scotter, 2008). Definisi lain dari pembalasan adalah serangkaian konsekuensi positif atau negatif yang dihadapi oleh pelapor sebagai pelaporan pelanggaran eksternal dari 81 jurusan akuntansi tentang implikasi pribadi dan sosial tertentu dari pelaporan penipuan keuangan. Hasil empiris menunjukkan korelasi negatif antara variabel biaya keuangan swasta dengan niat pelaporan pelanggaran. Studi lain oleh Fatoki (2013) menyelidiki 250 persepsi mahasiswa akuntansi akhir tahun tentang pelaporan pelanggaran dalam kaitannya dengan dampak kekuatan dan materialitas pembalasan. Hasil penelitian menunjukkan bahwa pembalasan berkorelasi negatif dengan kemungkinan niat pelaporan pelanggaran. Semakin kuat kekuatan pembalasan, semakin sedikit niat untuk mengadu.

Sebuah penelitian yang dilakukan oleh Elias dan Farag (2015) meneliti bagaimana pembalasan mempengaruhi persepsi mahasiswa akuntansi dalam auditor internal akan mengadu. Temuan mereka menunjukkan bahwa dibawah hasil pembalasan tertentu, ancaman pembalasan 
memiliki hubungan negatif dengan kemungkinan pelaporan pelanggaran. Studi oleh Cassematis dan Wortley (2013) menyelidiki kemungkinan untuk menggunakan rasa takut akan pembalasan dalam menentukan apakah karyawan sektor publik di Australia akan mengadu.

Hasilnya mengungkapkan bahwa ketakutan akan pembalasan melemahkan niat pelaporan pelanggaran mereka. Studi lain oleh Latan et al (2016) berpendapat bahwa variable pelaporan individu seperti dampak biaya pribadi mempengaruhi niat pelaporan pelanggaran akuntan publik Indonesia. kerja yang dapat mencakup keputusan tentang melaporkan pelanggaran atau bagaimana bereaksi sebagai penerima laporan tersebut.

Dalam studi yang komprehensif, studi literatur telah dilakukan untuk mendorong pelapor untuk membeberkan kasus yang terjadi. Namun, di beberapa bidang, pengetahuan tentang variabel pelaporan pelanggaran masih terbatas. Sintesis dari studi sebelumnya tentang variabel niat pelaporan pelanggaran yang didukung oleh artikel ini, bertujuan untuk mengidentifikasi kemungkinan untuk studi di masa depan

Tabel 6. Ringkasan Landasan Empiris Rasa Takut

\begin{tabular}{|c|c|c|c|}
\hline Studi & Negara & Metode & Temuan Utama \\
\hline $\begin{array}{l}\text { Kennett et } \\
\text { al. (2011) }\end{array}$ & $\begin{array}{l}\text { Amerika } \\
\text { Serikat }\end{array}$ & $\begin{array}{l}\text { Survei kuesioner kasus dari } 81 \text { jurusan } \\
\text { akuntansi dalam dua kursus akuntansi } \\
\text { tingkat senior di universitas Mid-western } \\
\text { regional. }\end{array}$ & $\begin{array}{l}\text { Variabel dampak biaya } \\
\text { keuangan pribadi berkorelasi } \\
\text { negatif dengan niat pelaporan } \\
\text { pelanggaran. }\end{array}$ \\
\hline $\begin{array}{l}\text { Elias dan } \\
\text { Farag } \\
(2015)\end{array}$ & $\begin{array}{l}\text { Amerika } \\
\text { Serikat }\end{array}$ & $\begin{array}{l}\text { Survei dari } 293 \text { jurusan akuntansi sarjana } \\
\text { dan pascasarjana senior yang terdaftar dalam } \\
\text { kursus Audit di dua universitas besar yang } \\
\text { terakreditasi AACSB. }\end{array}$ & $\begin{array}{l}\text { Ancaman pembalasan memiliki } \\
\text { hubungan negatif dengan } \\
\text { kemungkinan pelaporan } \\
\text { pelanggaran. }\end{array}$ \\
\hline $\begin{array}{l}\text { Fatoki } \\
(2013)\end{array}$ & $\begin{array}{l}\text { Selatan } \\
\text { Afrika }\end{array}$ & $\begin{array}{l}\text { Kuesioner dikumpulkan dari total } 219 \text { dari } \\
250 \text { mahasiswa akuntansi tahun terakhir dari } \\
\text { dua universitas berbeda di provinsi Gauteng } \\
\text { di Afrika Selatan. }\end{array}$ & $\begin{array}{l}\text { Niat pelaporan pelanggaran } \\
\text { melemah dengan ancaman } \\
\text { pembalasan menakutkan yang } \\
\text { lebih kuat. }\end{array}$ \\
\hline $\begin{array}{l}\text { Cassematis } \\
\text { dan } \\
\text { Wortley } \\
(2013)\end{array}$ & Australia & $\begin{array}{l}\text { 3-pertanyaan survei terdiri dari sketsa, opsi } \\
\text { tanggapan teks bebas dan tanggapan } \\
\text { kategoris kepada karyawan dari } 118 \\
\text { organisasi sektor publik Australia. }\end{array}$ & $\begin{array}{l}\text { Ketakutan akan pembalasan } \\
\text { berkontribusi pada keputusan } \\
\text { pengamat yang berbuat salah } \\
\text { untuk tetap diam. }\end{array}$ \\
\hline $\begin{array}{l}\text { Latan et al. } \\
(2016)\end{array}$ & Indonesia & $\begin{array}{l}\text { SurveiOnline pada } 256 \text { akuntan publik } \\
\text { Indonesia bekerja di perusahaan audit Big } 4 \\
\text { dan non-Big } 4 \text {. }\end{array}$ & $\begin{array}{l}\text { Akibat pelaporan pribadi } \\
\text { berpengaruh negatif terhadap } \\
\text { niat auditor untuk mengadu. }\end{array}$ \\
\hline
\end{tabular}

Sumber: Data Diolah (2019)

Temuan menunjukkan bahwa persepsi dampak biaya pelaporan yang dirasakan mempengaruhi niat pelaporan pelanggaran.

\section{Penutup}

Penelitian ini merangkum penelitian sebelumnya yang terkait dengan pelaporan pelanggaran yang ada. untuk beberapa profesi, pelaporan pelanggaran sangat penting. Pakar administrasi dan akuntansi menghadapi beragam pilihan etis di tempat untuk mendukung pelaporan pelanggaran.

\section{Daftar Referensi}

Ahmad, S. A. (2011). Internal auditor and internal whistleblowing intentions: A study of organizational, individual, situational and demographic factors. Unpublished doctoral thesis, Edith Cowan University. 
Ahmad, S., Smith, G. M., \& Ismail, Z. (2012). Internal whistleblowing intentions: A study of demographic and individual factors. Journal of Modern Accounting and Auditing, 5(11), 16321645 .

Alleyne, P., Hudaib, M., \& Pike, R. (2013). Towards a conceptual model of whistleblowing intentions among external auditors. The British Accounting Review, 45(1), 10-23. doi: 10.1016/j.bar.2012.12.003

Alleyne, P., Weekes-Marshall, D., \& Arthur, R. (2013). Exploring Factors Influencing Whistle-blowing Intentions among Accountants in Barbados. Journal of Eastern Caribbean Studies, 38(1), 3562.

Arnold Sr, D. F., Dorminey, J. W., Neidermeyer, A. A., \& Neidermeyer, P. E. (2013). Internal and external auditor ethical decision-making. Managerial Auditing Journal, 25(4), 300-322. doi: 10.1108/02686901311311918

Ballantine, P. (2002). Linking moral intensity to ethical decision-making: A crosscultural analysis of future marketers. ANZMAC 2002 Conference 2002 Proceedings, pp. 234. Diakses 16 Februari 2019, dari http://www.anzmac.org/conference arch ive/2002/

Bateman, C. R., Valentine, S., \& Rittenburg, T. L. (2013). Ethical decision making in a peer-to-peer file sharing situation: The role of moral absolutes and social consensus. Journal of Business Ethics, 115(2), 229-240. doi: 10.1007/s10551012-1388-1

Bhal, K. T. \& Dadhich, A. (2011). Impact of ethical leadership and leader-member exchange on whistleblowing: The moderating impact of the moral intensity of the issue. Journal of Business Ethics, 103(3), 485-496. doi: 10.1007/s10551011-0876-Z

Carlson, D. S., Kacmar, K. M., \& Wadsworth, L. L. (2009). The impact of moral intensity dimensions on ethical decision-making: Assessing the relevance of orientation. Journal of Managerial Issues, 21(4), 534-551. Diakses 16 Februari 2019, from http://www.jstor.org/stable/40604668

Cassematis, P. G., \& Wortley, R. (2013). Prediction of whistleblowing or nonreporting observation: The role of personal and situational factors. Journal of Business Ethics, 777(3), 615-634. doi: 10.1007/s10551-012-1548-3

Chartered Institute of Internal Auditors (IIA). (2014). Whistleblowing and Corporate Governance: The role of internal audit in whistleblowing. Diakses 16 Februari 2019, dari https://www.iia.org.uk/media/537988/fi nal_0795_iia_whistleblowing_report_30 $-1-\overline{1} 4 . \mathrm{pdf}$

Chen, C. P., \& Lai, C. T. (2014). To blow or not to blow the whistle: The effects of potential harm, social pressure and organisational commitment on whistleblowing intention and behaviour. Business Ethics: An European Review, 23(3), 327-342. doi: 10.1111/beer.12053

Chiu, R. K. (2002). Ethical judgment, locus of control, and whistleblowing intention: A case study of mainland Chinese MBA students. Managerial Auditing Journal, 17(9), $\quad 581-587 . \quad$ doi: $10.1108 / 02686900210447588$

Clements, L. H., \& Shawver, T. (2011). Moral intensity and intentions of accounting professionals to whistleblow internally. Journal of Forensic Studies in Accounting and Business, 3(1), 67-82.

Dozier, J.B. \& Miceli, M.P. (1985). Potential Predictors of Whistle-Blowing: A Prosocial Behavior Perspective. Academy of Management Review, 10, 823-836. doi:10.5465/amr.1985.4279105

Elias, R. Z. \& Farag, M. S. (2015). The relationship between professional skepticism and whistleblowing: Evidence of a retaliation effect. Franklin Business \& Law Journal, 2015(3), 1-28.

Erkmen, T., Çalışkan, A. O., \& Esen, E. (2014). An empirical research about 
whistleblowing behavior in accounting context. Journal of Accounting \& Organizational Change, 10(2), 229-243. doi: 10.1108/JAOC-03-2012-0028

Fatoki, O. (2013). Internal whistleblowing intentions of accounting students in South Africa: The impact of fear of retaliation, materiality and gender. Journal of Social Science, 37(1), 31-44.

Gaudine, A. \& Thorne, L. (2001). Emotion and Ethical Decision-Making in Organizations. Journal of Business Ethics, 31, 175-187. doi:10.1023/A:1010711413444

Jones, T. M. (1991). Ethical decision making by individuals in organizations: An issue-contingent model. The Academy of Management Review, 16(2), 366395. Diakses 16 Februari 2019, dari http://www.jstor.org/stable/258867

Keil, M., Tiwana, A., Sainsbury, R., et al. (2010). Toward a Theory of Whistleblowing Intentions: A Benefitto-Cost Differential Perspective. Decision Sciences, 41, 787-812. doi:10.1111/j.1540-5915.2010.00288.x

Kennett, D., Downs, A., \& Durler, M. G. (2011). Accounting students' intent to blow the whistle on corporate fraudulent financial reporting: An experiment. International Journal of Business and Social Science, 2(14).

Latan, H., Ringle, C. M., \& Chiappetta Jabbour, C. J. (2016). Whistleblowing intentions among public accountants in Indonesia: Testing for the moderation effects. Journal of Business Ethics, 138(1), 1-16. doi: 10.1007/s10551-0163318-0

Leitsch, D. L. (2006). Using dimensions of moral intensity to predict ethical decision-making in accounting. Accounting Education: An International Journal, 15(2), 135-149. doi: $10.1080=06939280600609151$

Lincoln, S. H., \& Holmes, E. K. (2011). Ethical decision making: a process influenced by moral intensity. Journal of Healthcare, Science and the Humanities, $1(1), 55-69$.
Mela, N. F., Zarefar, A., \& Andreas. (2016). The relationship of professional commitment of auditing student and anticipatory socialization toward whistleblowing intention. ProcediaSocial and Behavioral Sciences, 219, 507-512.

doi: 10.1016/j.sbspro.2016.05.027

Mencl, J., \& May, D. R. (2009). The effects of proximity and empathy on ethical decision-making: An exploratory investigation. Journal of Business Ethics, 85(2), 201-226. doi: 10.1007/s10551-008-9765-5

Miceli, M. P., \& Near, J. P. (1985). Characteristics of organizational climate and perceived wrong doing associated with whistle-blowing decisions. Personnel Psychology, 38, 525-544.

Miceli, M. P., Near, J. P., Rehg, M. T., \& Van Scotter, J. R. (2012). Predicting employee reactions to perceived organizational wrongdoing: Demoralization, justice, proactive personality, and whistleblowing. Human Relations, 65(8), 923-954. doi: $10.1177 / 0018726712447004$

Musbah, A., Cowton, C. J., \& Tyfa, D. (2016). The role of individual variables, organizational variables and moral intensity dimensions in Libyan management accountants' ethical decision making. Journal of Business Ethics, 134(3), 335-358. doi: 10.1007/s10551-014-2421-3

Mustapha, M., \& Siaw, L. S. (2012). Whistleblowing: Perceptions of future accountants. International Proceedings of Economics Development \& Research, 38, 135-139.

Near, J.P. and Miceli, M.P. (1985). Organizational Dissidence: The Case of Whistle-Blowing. Journal of Business Ethics, $\quad 4$, 1-16. doi:10.1007/BF00382668

Pillay, S., Dorasamy, N., \& Vranic, V. (2012). Exploring whistleblowing intentions in South Africa: A quantitative analysis. African Journal of 
Business Management, 6(7), 2529-2548. doi: $10.5897 /$ AJBM1 1.148

Rahimnia, F., \& Hassanzadeh, J. F. (2013). The impact of website content dimension and e-trust on e-marketing effectiveness: The case of Iranian commercial saffron corporations. Information \& Management, 50(5), 240247. doi: 10.1016/j.im.2013.04.003

Rehg, M. T., Miceli, M. P., Near, J. P., \& Van Scotter, J. R. (2008). Antecedents and outcomes of retaliation against whistleblowers: Gender differences and power relationships. Organization Science, 19(2), 221-240. doi: $10.1287 /$ orsc. $1070.0310 \mathrm{e}$

Salleh, K., \& Yunus, N. S. (2015). Encouraging factors for whistleblowing in public sector: Malaysian case evidence. Proceedings of the International Conference on Accounting Studies (ICAS 2015). (August 17-20 August 2015). Universiti Utara Malaysia (UUM). Johor, Malaysia.

Sampaio, D. B. D., \& Sorbal, F. (2013). Speak now or forever hold your peace? An essay on whistleblowing and its interfaces with the Brazilian culture. Brazilian Administration Review, 10(4), 370-388. doi: 10.1590/S180776922013000400002

Schmidtke, J. M. (2007). The relationship between social norm consensus, perceived similarity, and observer reactions to coworker theft. Human Resource Management, 46(4), 561-582. doi: 10.1002/hrm.20182

Shawver, T. J. (2011). The effects of moral intensity on whistleblowing behaviors of accounting professionals. Journal of Forensic \& Investigative Accounting, 3(2), 162-190.

Shawver, T. J., \& Clements, L. H. (2015). Are there gender differences when professional accountants evaluate moral intensity for earnings management? Journal of Business Ethics, 131(3), 557566. doi: 10.1007/s10551-014- 2293-6
Smith, B. R., Kistruck, G. M., \& Cannatelli, B. (2016). The impact of moral intensity and desire for control on scaling decisions in social entrepreneurship. Journal of Business Ethics, 133(4), 677689. doi: 10.1007/s10551-014-2447-6

Sweeney, B., \& Costello, F. (2009). Moral intensity and ethical decision-making: An empirical examination of undergraduate accounting and business students. Accounting Education: An International Journal, 18(1), 75-97. doi: $10.1080 / 09639280802009454$

Taylor, E. Z., \& Curtis, M. B. (2013). Whistleblowing in audit firms: Organizational response and power distance. Behavioral Research in Accounting, 25(2), 21-43. doi: 10.2308/bria-50415

Trevino, L.K., Weaver, G.R. and Reynolds, S.J. (2006). Behavioral Ethics in Organizations: A Review. Journal of Management, 32, 951-990. doi:10.1177/0149206306294258

Trongmateerut, P., \& Sweeney, J. T. (2013). The influence of subjective norms on whistle-blowing: A cross-cultural investigation. Journal of Business Ethics, 112(3), 437-451. doi: 10.1007/s10551-012-1270-1

Valentine, S., \& Hollingworth, D. (2012). Moral intensity, issue importance, and ethical reasoning in operations situations. Journal of Business Ethics, 108(4), 509-523. doi: 10.1007/s10551011-1107-3

Wainberg, J., \& Perreault, S. (2016). Whistleblowing in audit firms: Do explicit protections from retaliation activate implicit threats of reprisal? Behavioral Research in Accounting, 28(1), 83-93. doi: 10.2308/bria-51122

Wang, J., Keil, M., \& Wang, L. (2015). The effect of moral intensity on IT employees' bad news reporting. Journal of Computer Information Systems, 55(3), $1-10$. doi: 10.1080/08874417.2015.11645766 